\title{
Penerapan Metode Activity Based Costing (ABC) Dalam Penentuan \\ Tarif Jasa Rawat Inap Di Rumah Sakit Umum Daerah (RSUD) Hasanuddin Damrah Bengkulu Selatan
}

\author{
Mursalin \\ Akuntansi, FE Universitas PGRI Palembang, mursalin@univpgri-palembang.ac.id
}

\begin{abstract}
ABSTRAK
Dalam perhitungan biaya rawat inap kebanyakan rumah sakit masih menggunakan sistem biaya tradisional. Padahal perhitungan biaya rawat inap sangat penting, karena berkaitan dengan penentuan harga pokok jasa rawat inap yang pada akhirnya akan mempengaruhi penentuan harga jual atau tarif rawat inap. Alternatif yang dapat digunakan untuk menghitung biaya produk atau jasa adalah dengan menggunakan Activity Based Costing (ABC). Hasil penelitian menunjukkan bahwa dari perhitungan tarif rawat inap dengan menggunakan metode Activity Based Costing $(A B C)$, apabila dibandingkan dengan metode tradisional maka metode Activity Based Costing $(A B C)$ memberikan hasil yang lebih kecil pada semua kelas rawat inap. Hal ini disebabkan karena pembebanan biaya overhead pada masing-masing produk. Pada metode akuntansi biaya tradisional biaya overhead pada masing-masing produk hanya dibebankan pada satu cost driver saja. Akibatnya cenderung terjadi distorsi pada pembebanan biaya overhead. Sedangkan pada metode Activity Based Costing (ABC), biaya overhead pada masing-masing produk dibebankan pada banyak cost driver. Sehingga dalam metode Activity Based Costing $(A B C)$, telah mampu mengalokasikan biaya aktivitas ke setiap kamar secara tepat berdasarkan konsumsi masing-masing aktivitas.
\end{abstract}

Kata kunci: Tarif jasa, Activity Based Costing (ABC), Cost driver

\section{A. PENDAHULUAN}

Perkembangan dunia usaha yang semakin pesat mengakibatkan ketatnya persaingan bisnis. Masingmasing perusahaan saling beradu strategi dalam usaha menarik konsumen. Persaingan tersebut tidak hanya persaingan bisnis di bidang manufaktur atau industri tetapi juga di bidang usaha perdagangan dan pelayanan jasa. Salah satu bentuk usaha pelayanan jasa adalah jasa kesehatan, terutama jasa rumah sakit. Hal ini terbukti semakin banyak didirikannya rumah sakit baik milik pemerintah maupun swasta. Akibat dari perkembangan rumah sakit yang semakin pesat ini, menimbulkan persaingan yang ketat pula. Sehingga menuntut adanya persaingan atas produk dan kepercayaan pelanggan. Persaingan tersebut meliputi dari tarif jasa rawat inap, tarif jasa pengobatan rawat jalan, tarif jasa terapi kesehatan, tarif rontgen, dan lain-lain. Setiap rumah sakit bersaing sangat ketat dalam menentukan tarif-tarif tersebut untuk dapat menarik konsumen.

Rumah sakit dalam penentuan harga pokok produk terkadang masih menggunakan akuntansi biaya tradisional. Dimana akuntansi biaya tradisional memberikan informasi biaya yang terdistorsi. Semakin berkembangnya ilmu pengetahuan, lahirlah suatu sistem penentuan harga pokok produk berbasis aktivitas yang dirancang untuk mengatasi distorsi pada akuntansi biaya tradisional. Sistem akuntansi tersebut yaitu Activity Based Costing (ABC). Activity Based Costing (ABC) merupakan sebuah sistem informasi akuntansi yang mengidentifikasikan bermacam- 
macam aktivitas yang dikerjakan di dalam suatu organisasi dan mengumpulkan biaya dengan dasar sifat yang ada dari aktivitas tersebut.

Rumah Sakit Umum Daerah (RSUD) Hasanuddin Damrah Bengkulu Selatan adalah rumah sakit yang melayani kesehatan bagi masyarakat sekitar dan menampung pelayanan rujukan dari puskesmas. Dalam menentukan biaya rawat inap Rumah Sakit Umum Daerah (RSUD) Hasanuddin Damrah Bengkulu Selatan masih memakai sistem biaya tradisional, mengingat kompetitif persaingan antar rumah sakit, sistem yang digunakan oleh Rumah Sakit ini dianggap kurang mampu menyediakan informasi yang akurat.

\section{B. TINJAUAN TEORI}

1) Harga Pokok Produk atau Jasa Menurut Hansen dan Mowen (2004:40) jasa merupakan tugas atau aktivitas yang dilakukan untuk seorang pelanggan, atau aktivitas menggunakan produk atau fasilitas organisasi. Perlindungan asuransi, perawatan kesehatan, perawatan gigi, jasa pemakaman adalah contoh dari berbagai aktivitas jasa yang dilakukan untuk pelanggan.

Menurut Hansen dan Mowen (2004:146) perusahaan jasa adalah perusahaan yang menyediakan pelayanan jasa kepada konsumennya. Karakteristik yang dimiliki oleh perusahaan jasa yaitu:

a. Output sering didefinisikan dan tidak berwujud

b. Aktivitas untuk melakukan jasa lebih sulit untuk diprediksi

c. Biaya kapasitas gabungan mewakili sebagian besar proporsi total biaya dan sulit untuk dikaitkan dengan aktivitas-aktivitas menghasilkan output.

Biaya-biaya dalam perusahaan umumnya dibagi menjadi biaya langsung dan biaya tidak langsung. Biaya langsung adalah biaya yang dapat ditelusuri secara fisik ke produk atau jasa tertentu, seperti gaji yang dibayarkan kepada para perawat atau dokter, konsumsi. Sedangkan biaya tidak langsung adalah biaya yang tidak dapat ditelusuri ke produk atau jasa, seperti biaya asuransi, biaya iklan.

Dapat disimpulkan bahwa yang dimaksud dengan harga pokok produk atau jasa adalah jumlah dari total biaya yang dikeluarkan perusahaan untuk memproduksi produk atau jasa baik baya langsung maupun biaya tidak langsung. Namun, apabila perusahaan memproduksi lebih dari satu jenis produk atau jasa maka perlu perhitungan yang lebih akurat sehingga alokasi antara satu produk atau jasa dengan produk atau jasa yang lain sesuai dengan aktivitas atau kegiatan yang diakukan untuk memproduksi produk atau jasa tersebut, sehingga biaya yang terjadi adalah biaya yang sesuai dengan aktivitas produksi.

\section{2) Penetapan Harga}

Fungsi penetapan harga sangat penting, karena harga yang terlalu tinggi atau terlalu rendah bisa mengakibatkan kerugian bagi perusahaan. Menurut Hongren dan Foster (2003:86) terdapat tiga pengaruh utama terhadap keputusan penetapan harga yaitu:

1. Pelanggan

Manajer harus selalu mengkaji masalah-masalah penetapan harga dari sudut pandang pelanggan. Pelanggan mungkin akan menolak produk yang akan dijual suatu perusahaan dan memilih barang pengganti dengan biaya yang lebih efektif.

2. Pesaing

Ada tidaknya reaksi saingan akan mempengaruhi keputusan 
penetapan harga. Dalam meramalkan reaksi pesaing, analisis biaya pesaing dapat sangat berguna. Pengetahuan akan teknologi, ukuran pabrik, dan kebijakan operasi pesaing akan membantu mempertajam penaksiran biaya-biaya semacam itu.

3. Biaya

Harga maksimum yang mungkin dibebankan adalah harga yang tidak akan membuat pelanggan lari. Harga minimum adalah nol. Kadang-kadang perusahaan benarbenar akan menghadiahkan barangnya dalam usaha memasuki pasar atau untuk memperoleh hubungan jangka panjang yang menguntungkan dengan pelanggan.

3) Activity Base Costing (ABC)

a. Pengertian Activity Base Costing (ABC)

Menurut Dewi dan Kristato (2013:49) Activity Based Costing (ABC) Suatu sistem perhitungan biaya dimana tempat penampungan biaya overhead pabrik yang jumlahnya lebih dari satu, dialokasikan menggunakan dasar yang memasukan satu atau lebih faktor yang tidak berkaitan dengan volume.

Menurut Siregar, dkk (2013:232) Activity Based Costing (ABC) adalah suatu pendekatan perhitungan biaya yang membebankan biaya sumber daya ke dalam objek biaya, seperti produk, jasa, atau konsumen berdasarkan aktivitas yang dilakukan untuk objek biaya.

Menurut Mulyadi (2007:96) Activity Based Costing (ABC) adalah sistem informasi biaya berbasis aktivitas yang didesain untuk memotivasi personel dalam melakukan pengurangan biaya dalam jangka panjang melalui pengelolaan aktivitas.

\section{b. Sejarah Activity Based Costing (ABC)}

Menurut Mulyadi (2007:51) pada tahap awal perkembangannya, Activity Based Costing (ABC) dimanfaatkan untuk memperbaiki kecermatan perhitungan kos produk dalam perusahaan-perusahaan manufaktur yang menghasilkan banyak jenis produk. Pada perkembangan selanjutnya, Activity based costing (ABC) tidak lagi terbatas pemanfaatannya hanya untuk manghasilkan informasi cost produk yang akurat, namun meluas sebagai sistem informasi untuk memotivasi personel dalam melakukan improvement terhadap proses yang digunakan oleh perusahaan untuk menghasilkan produk/jasa bagi customer.

Jika pada tahap awal perkembangannya, Activity based costing $(\mathrm{ABC})$ hanya difokuskan pada biaya overhead pabrik, pada tahap perkembangan selanjutnya, Activity based costing (ABC) diterapkan ke semua biaya, mulai dari biaya desain, biaya produksi, biaya penjualan, biaya pasca jual, sampai biaya administrasi dan umum. Activity based costing (ABC) menggunakan aktivitas tidak hanya dijumpai di perusahaan manufaktur dan tidak terbatas di tahap produksi, maka Activity based costing (ABC) dapat dimanfaatkan di berbagai jenis organisasi dan mencakup biaya di luar produksi.

\section{c. Penerapan Activity Based Costing (ABC) \\ Menurut Siregar, dkk (2013:234)} proses penerapan Activity Based Costing $(\mathrm{ABC})$ dapat dibagi menjadi dua tahap yaitu:

> Tahap Pertama

Pada tahap ini penerapan metode Activity Based Costing (ABC) adalah melakukan analisis aktivitas 
untuk mengidentifikasi biaya sumber daya dan aktivitas di perusahaan. kebanyakan perusahaan, pencatatan biaya sumber daya dilakukan pada rekening-rekening yang spesifik dalam sistem akuntansinya sebagai berikut:

1) Mengidentifikasi aktivitas

2) Membebankan biaya ke pool biaya aktivitas

3) Aktivitas yang berkaitan di kelompokan untuk membentuk kumpulan sejenis

4) Biaya aktivitas yang di kelompokan di jumlah untuk mengidentifikasi kelompok biaya sejenis

5) Menghitung tarif overhead kelompok

\section{$>$ Tahap Kedua}

Dalam tahap ini biaya setiap kelompok overhead ke pabrik dengan menggunakan tarif kelompok yang dikonsumsi oleh masing-masing produk, sehingga biaya aktivitas yang ada dibebankan kepada produk terhadap setiap aktivitas. Kemudian biaya overhead per-unit di peroleh dengan menelusuri biaya-biaya overhead dari kelompok-kelompok tertentu pada produk. Total biaya tersebut kemudian di bagi dengan jumlah unit yang diproses dan akan menghasilkan biaya overhead perunit. Proses penerapan Activity Based Costing ( $\mathrm{ABC}$ ) menjadi enam tahap:

1) Mengidentifikasi dan mendefinisikan aktivitas dan pool aktivitas

2) Bila mungkin, menelusuri langsung ke aktivitas dan objek biaya

3) Membebankan biaya ke pool biaya aktivitas

4) Menghitung tarif aktivitas

5) Mebebankan biaya ke objek dengan menggunakan tarif aktifitas dan ukuran aktivitas

6) Menyusun laporan manajemen.

Berdasarkan pendapat-pendapat diatas mengenai langkah-langkah dalam penerapan Activity Based Costing (ABC), maka dapat disimpulkan bahwa tahap-tahap penerapan Activity Based Costing $(A B C)$ secara umum yaitu:

1) Mengidentifikasi aktivitas utama

2) Menentukan biaya aktivitasaktivitas tersebut

3) Mengidentifikasi ukuran konsumsi untuk biaya aktivitas

4) Menghitung tarif aktivitas

5) Mengukur permintaan aktivitas tiap produk

6) Menghitung biaya produk.

d. Komponen untuk Membentuk Activity Based Costing (ABC)

Menurut Rudianto (2005:275) dalam penerapan Activity Based Costing ( $\mathrm{ABC}$ ) ada empat komponen utama yang perlu diperhatikan yaitu:

1. Aktivitas adalah pekerjaan utama yang diperlukan dalam suatu organisasi. Aktivitas adalah tindakan, gerakan atau rangkaian pekerjaan. Aktivitas dapat pula diartikan sebagai kumpulan tindakan yang dilakukan dalam organisasi yang berguna untuk tujuan penentuan biaya berdasarkan aktivitas. Aktivitas adalah segala sesuatu yang menyebabkan konsumsi overhead. Biaya untuk melakukan aktivitas dibebankan ke produk yang menyebebkan aktivitas tersebut.

2. Sumber daya adalah umur ekonomis yang dibebankan atau digunakan dalam pelaksanaan aktivitas. Gaji dan bahan merupakan contoh sumber daya yang digunakan untuk melakukan aktivitas.

3. Elemen biaya adalah jumlah yang dibayarakan untuk sumber daya yang dikonsumsi oleh aktivitas dan terkadang di dalam cost pool. Misalnya cost pool untuk hal-hal yang berkaitan dengan mesin mungkin mengandung elemen 
biaya untuk tenaga, elemen biaya teknik dan elemen biaya depresiasi.

4. Pemicu biaya atau cost driver adalah faktor-faktor yang menyebabkan perubahan biaya aktivitas. Cost driver merupakan faktor yang dapat diukur yang digunakan untuk membebankan boaya ke aktivitas dan dari aktivitas ke aktivitas lainnya, produk atau jasa. Dua jenis pemicu biaya yang dikenal adalah pemicu sumber daya dan pemicu aktivitas.

\section{e. Cost Driver, Cost Pool, dan Cost Object}

Menurut Siregar (2013:240) pemicu biaya (cost driver) adalah suatu faktor yang menyebabkan atau berhubungan dengan perubahan biaya dari suatu aktivitas.

Menurut Mulyadi (2007:83) cost pool adalah akun yang digunakan untuk menggabungkan biaya dua atau lebih aktivitas yang memiliki Activity Driver yang sama untuk dapat dibebankan secara bersama-sama ke produk/jasa dengan menggunakan hanya satu Activity Driver.

Menurut Ahmad (2014:14) objek biaya (cost object) adalah produk, jasa atau unit organisasi di mana biaya dibebankan untuk beberapa tujuan manajemen.konsep cost object merupakan konsep yang luas. Konsep tersebut tidak hanya meliputi produk,jasa dan departemen tetapi juga kelompok produk, jasa, departemen pelanggan, supplier provider jasa telepon, dan lain-lain.

\section{f. Manfaat Activity Based Costing $(A B C)$}

Awalnya tujuan perusahaan menggunakan Activity Based Costing (ABC) adalah untuk mengurangi distorsi dalam peritungan biaya produk yang sering dijumpai dalam sistem biaya berbasis unit. Manfaat lain dari Activity Based Costing (ABC) menurut Siregar, dkk (2013:239) yaitu:

1) Pengukuran profitabilitas yang lebih baik. Biaya setiap aktivitas dapat dibebankan dengan lebih akurat dan terperinci ke dalam produk atau jasa sehingga hasil penawaran produk atau jasa menjadi lebih mudah ditelusur. Selain itu, profitabilitas juga menjadi lebih mudah diketahui kaitannya dengan suatu produk atau jasa.

2) Pembuatan keputusan yang lebih baik. Informasi penggunaan aktivitas yang lebih detail menjadikan manajemen dapat menganalisis dampak atau hasil dari suatu aktivitas sehingga dapat memberi dasar pembuatan keputusan yang lebih akurat.

3) Perbaikan proses (proses improvement). Activity Based Costing (ABC) memberikan informasi detail mengenai penggunaan aktivitas. Hal ini memudahkan menajemen menelusuri dan menganalisis efektivitas dan efesiensi biaya aktivitas. Kemudian, aktivitasaktivitas yang dianggap tidak memberi nilai tambah dapat dihilangkan sementara aktivitasaktivitas yang belum optimal dapat dioptimalkan.

4) Estimasi biaya. Ketersediaan informasi penggunaan aktivitas dan biaya di masa lalu yang terperinci dapat memberikan dasar yang akurat dalam penentuan estimasi biaya di masa depan.

5) Penentuan biaya kapasitas tak terpakai. Estimasi biaya yang akurat atas suatu aset atau sumber daya pada suatu kapasitas yang dianggarakan dapat menjadi dasar penentu nilai biaya dari kapasitas yang tidak digunakan akibat tidak efisiensi produksi atau pelayanan. 
4) Metode Akuntansi Biaya Tradisional (Traditional Costing)

Metode akuntansi biaya tradisional yang menggunakan pemadu biaya yang berhubungan dengan volume produksi beranggapan bahwa biaya-biaya akan meningkatkan secara propesional dengan besarnya volume output. Sistem ini tidak dapat menjelaskan mengapa biaya-biaya produksi semakin meningkat dengan hasil yang semakin beragam. Metode akuntansi biaya tradisional rentan akan kelemahan yang dapat mengakibatkan untuk pembuatan keputusan terdistorsi. Metode ini cenderung mengandalkan alokasi tingkat unit. Akhirnya produk dibebani oleh sumber daya yang tidak digunakan.

Definisi sistem akuntansi biaya tradisional menurut Carter dan Usri (2006:496) menyatakan bahwa perhitungan biaya tradisional hanya menelusuri biaya bahan baku langsung dan biaya tenaga kerja langsung ke setiap unit output.

\section{5) Perbedaan Metode Akuntansi Biaya Tradisional dengan Activity Based Costing (ABC) \\ Dalam penerapannya metode} akuntansi biaya tradisional dengan Activity Based Costing (ABC) terdapat perbedaan. Menurut Tunggal (2012:26) perbedaan dari kedua metode tersebut, yaitu:

1. Activity Based Costing (ABC) menggunakan aktivitas-aktivitas sebagai pemacu untuk menentukan berapa besar setiap overhead tidak langsung dari setiap produk mengkonsumsikan. Sistem tradisional mengalokasikan overhead secara arbitrer berdasarkan satu atau dua basis alokasi yang non representatif, dengan demikian gagal menyerap konsumsi overhead yang benar menurut produk individual.

2. Fokus activity based costing (ABC) adalah pada biaya, mutu, dan faktor waktu. Sistem tradisional terutama memfokus pada kinerja keuangan jangka pendek, seperti laba, dengan cukup akurat. Apabila sistem tradisional digunakan untuk penetapan harga dan untuk mengidentifikasi produk yang menguntungkan, angka-angkanya tidak dapat diandalkan atau dipercaya.

3. Activity based costing (ABC) membagi konsumsi overhead ke dalam empat kategori: unit, batch, produk, dan "penopang fasilitas (facility substaining)". Sistem tradisional membagi biaya overhead kedalam unit dan yang lain. Sebagai akibatnya activity based costing $(\mathrm{ABC})$ mengkalkulasi konsumsi sumber daya, tidak semata-mata pengeluaran organisasional.

4. Activity based costing ( $\mathrm{ABC}$ ) mempunyai yang jauh lebih kecil untuk analisis varian dari pada sistem tradisional, karena kelompok biaya (cost pools) dan pamacu (driver) jauh lebih akurat dan jelas, dan karena activity based costing (ABC) dapat menggunakan biaya aktual apabila kebutuhan muncul.

5. Activity based costing (ABC) memerlukan masukan dari seluruh departemen. Persyaratan ini mengarah ke integrasi organisasi yang lebih baik dan memberikan suatu pandangan fungsional silang mengenai organisasi. 
6) Kerangka Pemikiran

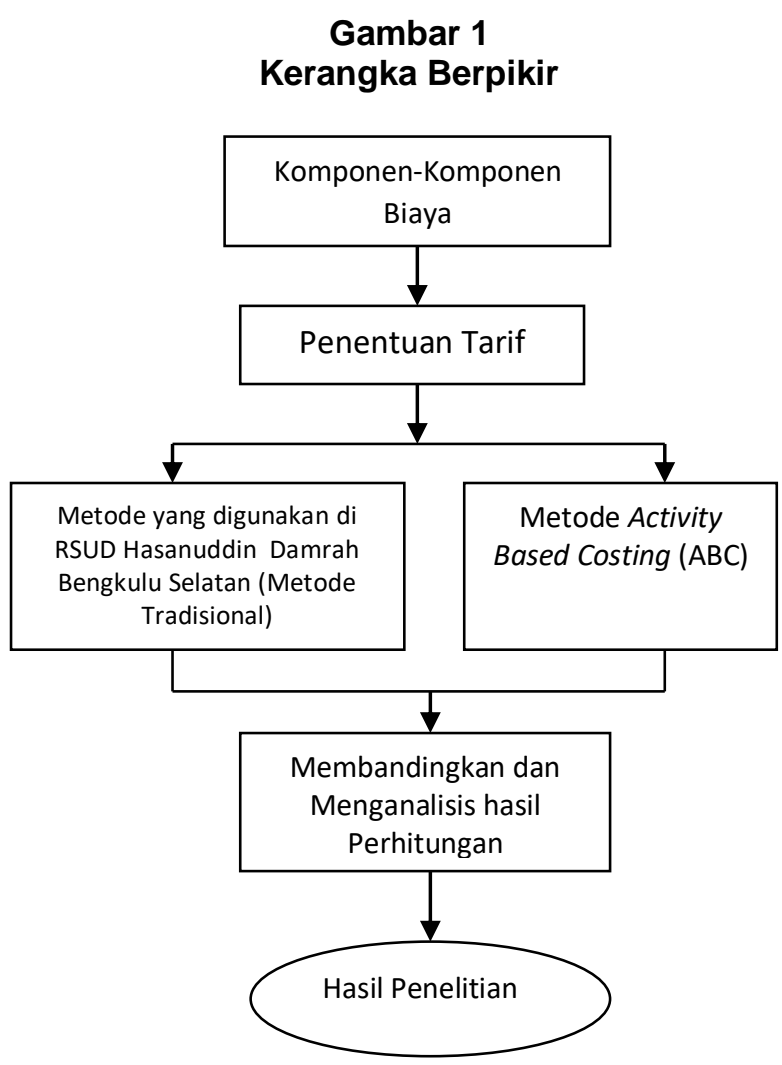

\section{METODE PENELITIAN}

Metode penelitian yang digunakan dalam penelitian ini adalah metode kualitatif. Menurut Kurniawan (2014:110) metode kualitatif adalah metode penelitian yang digunakan untuk menyelidiki, menemukan, menggambarkan, dan menjelaskan kualitas atau keistimewaan dari pengaruh sosial yang tidak dapat dijelaskan, diukur atau digambarkan melalui penelitian kuantitatif.

\section{POPULASI DAN SAMPEL \\ 1. Populasi}

Populasi dalam penelitian ini adalah seluruh kamar rawat inap di Rumah Sakit Umum Daerah (RSUD) Hasanuddin Damrah Bengkulu Selatan.

\section{Sampel}

Sampel dari penelitin ini adalah kamar rawat inap di ruangan VIP, kelas 1, kelas 2, dan kelas 3 di Rumah Sakit Umum Daerah (RSUD)
Hasanuddin Damrah Bengkulu Selatan selama tahun 2018.

\section{E. VARIABEL PENELITIAN}

Variabel yang digunakan dalam penelitian ini adalah Metode Activity Based Costing (ABC) dalam penentuan tarif jasa rawat inap Rumah Sakit Hasanuddin Damrah Bengkulu Selatan.

\section{F. INSTRUMEN PENELITIAN}

Sehubungan dengan pokok masalah yang dibahas dapat dikemukakan definisi operasional variabel yang akan dijadikan acuan adalah "Activity Based Costing merupakan suatu sistem perhitungan biaya dimana tempat penampungan biaya overhead pabrik yang jumlahnya lebih dari satu, dialokasikan menggunakan dasar yang memasukan satu atau lebih faktor yang tidak berkaitan degan volume" (Dewi dan Kristato, 2013:49).

\section{G. SUMBER DATA DAN TEKNIK PENGUMPULAN DATA}

\section{Sumber Data}

Sumber data yang digunakan dalam penelitian ini adalah menggunakan data sekunder. Menurut Sugiyono (2015:152) data sekunder adalah data yang mengacu pada informasi yang dikumpulkan dari sumber yang telah ada. Sumber data sekunder adalah catatan atau dokumentasi perusahaan, publikasi pemerintah, analisis industri oleh media, situs web, internet dan seterusnya.

\section{Teknik Pengumpulan Data}

Dalam penelitian ini teknik pengumpulan data yang digunakan adalah:

a. Dokumentasi

Teknik pengumpulan data sekunder melalui dokumen-dokumen yang ada hubungannya dengan penelitian yang akan dilakukan. 
b. Studi pustaka

Teknik pengumpulan data dengan cara mengadakan studi kepustakaan untuk mendapatkan teori-teori pendukung yang dijadikan acuan untuk analisis dan pembahasan dalam penulisan ini.

\section{H. TEKNIK ANALISIS DATA}

Data yang diperlukan diperoleh dengan cara pengumpulan data, kemudian dianalisis berdasarkan pertanyaan penelitian. Data yang diperlukan adalah tentang aktivitasaktivitas biaya rawat inap. Setelah pengumpulan data selesai, dilakukan perhitungan biaya dengan menggunakan sistem Activity Based Costing ( $\mathrm{ABC}$ ) melalui tiga tahap, yaitu:

\section{Tahap pertama}

Meminta data tentang daftar tarif rawat inap yang digunakan oleh pihak Rumah Sakit Umum Daerah (RSUD) Hasanuddin Damrah Bengkulu Selatan selama ini.

\section{Tahap Kedua}

Menghitung biaya rawat inap dengan cara pengumpulan biaya dalam cost pool yang memiliki aktivitas yang sejenis atau homogen, terdiri dari empat langkah:

a. Mengidentifikasikan aktivitas

b. Mengidentifikasi cost driver

c. Menentukan tarif per unit cost driver

Menurut Supriyono (2002:232) untuk menentukan tarif per unit dihitung dengan rumus: Tarif Per unit Cost Driver $=\frac{\text { Jumlah Aktivitas }}{\text { Cost Driver }}$

d. Membebankan biaya ke produk dengan menggunakan tarif cost driver dan ukuran aktivitas.

1. Pembebanan biaya overhead dari tiap aktivitas ke setiap kamar dihitung dengan rumus menurut Supriyono (2002:234) yaitu:

$$
\begin{aligned}
& \text { BOP yang dibebankan }=\text { tarif/unit drivers } x \text { cost } \\
& \text { drivers yang dipilih }
\end{aligned}
$$

Tarif per kamar = Cost Rawat Inap +Laba yang diharapkan

\section{Tahap Ketiga}

Membandingkan tarif rawat inap rumah sakit berdasarkan activity based costing (ABC)dengan realisasi. Kemudian menganalisis harga rawat inap antara kedua metode tersebut dan membuat kesimpulan.

\section{HASIL PENELITIAN}

1. Kelas Jasa Rawat Inap RSUD Hasanuddin Damrah Bengkulu Selatan

Kelas rawat inap pada RSUD Hasanuddin Damrah Bengkulu Selatan terdiri atas kelas VIP, kelas 1, kelas 2, kelas 3. Fasilitas yang disediakan pada masing-masing

\begin{tabular}{|c|c|c|c|c|}
\hline No & $\begin{array}{l}\text { Kel } \\
\text { as }\end{array}$ & Fasilitas & $\begin{array}{l}\text { Jumlah } \\
\text { Pasien }\end{array}$ & $\begin{array}{c}\text { Tarif/Hari } \\
(R p)\end{array}$ \\
\hline 1 & VIP & $\begin{array}{l}1 \text { bed pasien, } \\
\text { bantal, selimut, } \\
\text { sprei, tiang infus, } \\
\text { meja, AC, televisi, } \\
\text { kulkas, lemari } \\
\text { kecil, kursi } \\
\text { penunggu di } \\
\text { dalam, kursi } \\
\text { penunggu di luar } \\
\text { kamar, kamar } \\
\text { mandi }\end{array}$ & $\begin{array}{c}\text { Satu } \\
\text { kamar } \\
\text { ditempati } \\
1 \text { orang } \\
\text { pasien }\end{array}$ & 250.000 \\
\hline 2 & 1 & $\begin{array}{l}1 \text { bed pasien, } \\
\text { bantal, selimut, } \\
\text { sprei, tiang infus, } \\
\text { meja, AC, lemari } \\
\text { kecil, televisi, } \\
\text { kursi penunggu di } \\
\text { luar kamar, kamar } \\
\text { mandi }\end{array}$ & $\begin{array}{c}\text { Satu } \\
\text { kamar } \\
\text { ditempati } \\
1 \text { orang } \\
\text { pasien }\end{array}$ & 150.000 \\
\hline
\end{tabular}
kelas, dapat dilihat pada tabel berikut ini:

Tabel 1

Fasilitas Jasa Rawat Inap

RSUD Hasanuddin Damrah Bengkulu Selatan 


\begin{tabular}{|c|c|l|c|c|}
\hline 3 & 2 & $\begin{array}{l}1 \text { bed pasien, } \\
\text { bantal, selimut, } \\
\text { sprei, tiang infus, } \\
\text { meja, AC, lemari } \\
\text { kecil, kursi } \\
\text { penunggu di luar } \\
\text { kamar, kamar } \\
\text { mandi }\end{array}$ & $\begin{array}{c}\text { Satu } \\
\text { kamar } \\
\text { ditempati } \\
2 \text { orang } \\
\text { pasien }\end{array}$ & 100.000 \\
\hline 4 & 3 & $\begin{array}{l}1 \text { bed pasien, } \\
\text { bantal, selimut, } \\
\text { sprei, tiang infus, } \\
\text { meja, kipas angin, } \\
\text { lemari kecil, kursi } \\
\text { penunggu di luar } \\
\text { kamar }\end{array}$ & $\begin{array}{c}\text { Satu } \\
\text { kamar } \\
\text { ditempati } \\
\text { 6 orang } \\
\text { pasien }\end{array}$ & 75.000 \\
\hline
\end{tabular}

Sumber : RSUD Hasanuddin Damrah Bengkulu Selatan (2018)

Tabel 2

Jumlah Pasien Rawat Inap

RSUD Hasanuddin Damrah

Bengkulu Selatan

Tahun 2018

\begin{tabular}{|c|c|c|c|c|}
\hline \multirow{2}{*}{ Bulan } & \multicolumn{4}{|c|}{ Kelas } \\
\hline & VIP & 1 & 2 & 3 \\
\hline Januari & 14 & 40 & 102 & 135 \\
\hline Februari & 20 & 48 & 112 & 147 \\
\hline Maret & 21 & 38 & 95 & 158 \\
\hline April & 14 & 49 & 117 & 178 \\
\hline Mei & 19 & 41 & 109 & 160 \\
\hline Juni & 13 & 44 & 121 & 149 \\
\hline Juli & 14 & 35 & 91 & 164 \\
\hline Agustus & 17 & 38 & 102 & 170 \\
\hline September & 15 & 47 & 113 & 181 \\
\hline Oktober & 21 & 49 & 106 & 176 \\
\hline November & 18 & 40 & 90 & 170 \\
\hline Desember & 19 & 46 & 105 & 187 \\
\hline Jumlah & 205 & 515 & 1.263 & 1.975 \\
\hline
\end{tabular}

\section{Data Aktivitas RSUD Hasanuddin Damrah Bengkulu Selatan}

Data aktivitas pada penelitian ini adalah data yang berhubungan dengan aktivitas di unit rawat inap yaitu: a. Input, merupakan pasien yang melakukan rawat inap di RSUD Hasanuddin Damrah Bengkulu Selatan.

b. Proses, kegiatan yang meliputi aktivitas-aktivitas pada unit rawat inap seperti:

c. Output, merupakan hari pasien menginap selama dirawat di RSUD Hasanuddin Damrah Bengkulu Selatan.

d. Pemicu biaya.

\section{Data Biaya RSUD Hasanuddin Damrah Bengkulu Selatan}

Data biaya pada penelitian ini adalah seluruh biaya yang dikeluarkan oleh pihak rumah sakit yang berhubungan dengan aktivitas atau kegiatan rawat inap. Adapun data biaya yang ada pada penelitian ini adalah:

Tabel 3

Biaya yang Dikeluarkan pada Tahun 2018 RSUD Hasanuddin Damrah Bengkulu Selatan

\begin{tabular}{|c|c|c|c|}
\hline No & Uraian Biaya & Biaya (Rp) & $\begin{array}{c}\text { Jumlah Biaya } \\
\text { (Rp) }\end{array}$ \\
\hline \multirow[t]{5}{*}{1} & $\begin{array}{l}\text { Biaya Tenaga } \\
\text { Kerja }\end{array}$ & & 708.000 .000 \\
\hline & Gaji Perawat & 384.000 .000 & \\
\hline & Dapur & 84.000 .000 & \\
\hline & $\begin{array}{l}\text { Petugas } \\
\text { Kebersihan }\end{array}$ & 192.000 .000 & \\
\hline & Administrasi & 48.000 .000 & \\
\hline \multirow[t]{3}{*}{2} & Biaya Listrik & & 239.246 .300 \\
\hline & $\begin{array}{l}\text { Penyediaan } \\
\text { fasilitas }\end{array}$ & 236.375 .300 & \\
\hline & $\begin{array}{l}\text { Penyediaan } \\
\text { makanan }\end{array}$ & 2.871 .000 & \\
\hline \multirow[t]{4}{*}{3} & Biaya Air & & 16.045 .146 \\
\hline & $\begin{array}{l}\text { Penyediaan } \\
\text { Fasilitas }\end{array}$ & 9.627 .087 & \\
\hline & $\begin{array}{l}\text { Penyediaan } \\
\text { Makanan }\end{array}$ & 4.011 .287 & \\
\hline & $\begin{array}{l}\text { Kegiatan } \\
\text { Kebersihan }\end{array}$ & 2.406 .772 & \\
\hline 4 & $\begin{array}{l}\text { Biaya } \\
\text { Administrasi }\end{array}$ & & 72.182 .509 \\
\hline 5 & $\begin{array}{l}\text { Biaya } \\
\text { Kebersihan }\end{array}$ & & 6.138 .000 \\
\hline 6 & Biaya Laundry & & 10.870 .000 \\
\hline 7 & $\begin{array}{l}\text { Biaya } \\
\text { Konsumsi } \\
\text { Pasien }\end{array}$ & & 389.885 .000 \\
\hline 8 & $\begin{array}{l}\text { Biaya } \\
\text { Pemeliharaan }\end{array}$ & & 96.200 .000 \\
\hline
\end{tabular}




\begin{tabular}{|l|l|l|r|}
\hline 9 & $\begin{array}{l}\text { Biaya } \\
\text { Depresiasi } \\
\text { Gedung }\end{array}$ & 51.714 .985 \\
\hline 10 & $\begin{array}{l}\text { Biaya } \\
\text { Depresiasi } \\
\text { Fasilitas }\end{array}$ & & 77.300 .188 \\
\hline \multicolumn{2}{|c|}{ Jumlah } & 1.667 .582 .128 \\
\hline
\end{tabular}

Sumber: Diolah oleh penulis (2018)

\section{J. PEMBAHASAN}

1. Mengidentifikasikan aktivitas Pada langkah ini biaya digolongkan kedalam aktivitas yang terdiri dari empat kategori yaitu:

a. Aktivitas Berlevel Unit (Unit Level Activities)

b. Aktivitas Berlevel Batch (Batch Level Activities)

c. Aktivitas Berlevel Produk (Produk Level Activities)

d. Aktivitas Berlevel Fasilitas (Fasility Level Activities.

Tabel 4

Klasifikasi Biaya Ke

Dalam Berbagai Aktivitas

RSUD Hasanuddin Damrah

Bengkulu Selatan

Tahun 2018

\begin{tabular}{|c|c|}
\hline Elemen Biaya & Jumlah (Rp) \\
\hline \multicolumn{2}{|c|}{ Unit-level activity cost } \\
\hline Biaya tenaga kerja & 708.000 .000 \\
\hline Biaya listrik & 239.246 .300 \\
\hline Biaya air & 16.045 .146 \\
\hline Biaya laundry & 10.870 .000 \\
\hline Biaya konsumsi & 389.885 .000 \\
\hline \multicolumn{2}{|c|}{ Batch-related activity cost } \\
\hline Biaya kebersihan & 6.138 .000 \\
\hline Biaya administrasi & 72.182 .509 \\
\hline \multicolumn{2}{|c|}{ Fasility-sustaining activity cost } \\
\hline Biaya depresiasi gedung & 51.714 .985 \\
\hline Biaya depresiasi fasilitas & 77.300 .188 \\
\hline Biaya pemeliharaan & 96.200 .000 \\
\hline Total & 1.667 .582 .128 \\
\hline
\end{tabular}

Sumber: Diolah oleh penulis (2018)

2. Mengidentifikasi cost driver Identifikasi cost driver dimaksudkan untuk memudahkan dalam penentuan tarif perunit cost driver. Setelah aktivitas-aktivitas ini diidentifikasi sesuai dengan kategorinya, langkah selanjutnya adalah mengidentifikasi cost driver dari setiap biaya aktivitas. Pengidentifikasian ini dimaksudkan dalam penentuan kelompok aktivitas dan tarif/unit cost driver.

3. Menentukan tarif per unit cost driver

Setelah mengidentifikasi cost driver, kemudian menentukan tarif per unit cost driver. Karena setiap aktivitasnya memiliki cost driver dengan cara membagi jumlah biaya dengan cost driver dapat dihitung dengan menggunakan rumus:

Menurut Supriyono (2002:232)

Tarif Per unit Cost Drivers $=\frac{\text { jumlah aktivitas }}{\text { cost drivers }}$

Tabel 5

Penentuan Tarif Per-Unit Cost Driver Kamar Rawat Inap

Metode Activity Based Costing (ABC) RSUD Hasanuddin Damrah Bengkulu Selatan

Tahun 2018

\begin{tabular}{|c|c|c|c|c|}
\hline No & Aktivitas & $\begin{array}{l}\text { Jumlah } \\
\text { (Rp) }\end{array}$ & $\begin{array}{c}\text { Cost } \\
\text { Driver }\end{array}$ & $\begin{array}{l}\text { Tarif / Unit } \\
\text { (Rp) }\end{array}$ \\
\hline 1 & \multicolumn{4}{|l|}{ Unit level activity cost } \\
\hline & $\begin{array}{l}\text { a. Biaya Tenaga } \\
\text { Kerja }\end{array}$ & 708.000 .000 & 22.327 & $31.710,49$ \\
\hline & 1. Kelas VIP & & 1.353 & \\
\hline & 2. Kelas 1 & & 2.661 & \\
\hline & 3. Kelas 2 & & 7.398 & \\
\hline & 4. Kelas 3 & & 10.915 & \\
\hline & b. Biaya listrik & 239.246 .300 & $338.463,42$ & 706,86 \\
\hline & 1. Kelas VIP & & $37.207,5$ & \\
\hline & 2. Kelas 1 & & $65.141,28$ & \\
\hline & 3. Kelas 2 & & 181.103 .04 & \\
\hline & 4. Kelas 3 & & $55.011,6$ & \\
\hline & c. Biaya Air & 16.045 .146 & 22.327 & 718,643 \\
\hline & 1. Kelas VIP & & 1.353 & \\
\hline & 2. Kelas 1 & & 2.661 & \\
\hline & 3. Kelas 2 & & 7398 & \\
\hline & 4. $\quad$ Kelas 3 & & 10.915 & \\
\hline & $\begin{array}{ll}\text { d. } & \text { Biaya } \\
& \text { laundry }\end{array}$ & 10.870 .000 & 22.327 & 486,85 \\
\hline & 1. Kelas VIP & & 1.353 & \\
\hline & 2. Kelas 1 & & 2.661 & \\
\hline & 3. Kelas 2 & & 7.398 & \\
\hline & 4. Kelas 3 & & 10.915 & \\
\hline & $\begin{array}{ll}\text { e. } & \begin{array}{l}\text { Biaya } \\
\text { konsumsi }\end{array}\end{array}$ & 389.885 .000 & 66.981 & 5820,83 \\
\hline & 1. Kelas VIP & & 4.059 & \\
\hline & 2. Kelas 1 & & 7.983 & \\
\hline & 3. Kelas 2 & & 22.194 & \\
\hline & 4. Kelas 3 & & 32.745 & \\
\hline & \multicolumn{4}{|c|}{ Batch related activity cost } \\
\hline & $\begin{array}{l}\text { a. Biaya } \\
\text { kebersihan }\end{array}$ & 6.138 .000 & 1.895 & $3.239,05$ \\
\hline & 1. Kelas VIP & & 362 & \\
\hline & 2. Kelas 1 & & 362 & \\
\hline & 3. Kelas 2 & & 550 & \\
\hline & 4. Kelas 3 & & 621 & \\
\hline & $\begin{array}{l}\text { b.Biaya } \\
\text { administrasi }\end{array}$ & 72.182 .509 & 3.958 & $18.237,12$ \\
\hline & 1. Kelas VIP & & 205 & \\
\hline & 2. Kelas 1 & & 515 & \\
\hline & 3. Kelas 2 & & 1.263 & \\
\hline & 4. Kelas 3 & & 1.975 & \\
\hline & & & asility sustain & activity cost \\
\hline & $\begin{array}{l}\text { a. Biaya depr. } \\
\text { gedung }\end{array}$ & 51.714 .985 & 1.895 & $27.290,23$ \\
\hline & 1. Kelas VIP & & 362 & \\
\hline
\end{tabular}




\begin{tabular}{|c|c|c|c|}
\hline 2. Kelas 1 & & 362 & \\
\hline 3. Kelas 2 & & 550 & \\
\hline 4. $\quad$ Kelas 3 & & 621 & \\
\hline $\begin{array}{ll}\text { b. } & \text { Biaya depr. } \\
\text { fasilitas }\end{array}$ & & & \\
\hline 1. $\mathrm{AC}(\mathrm{VIP}, \mathrm{K} 1, \mathrm{~K} 2)$ & 40.500 .000 & 11.412 & $3.548,90$ \\
\hline 2. $\mathrm{TV}(\mathrm{VIP}, \mathrm{K} 1)$ & 4.750 .000 & 4.014 & $1.183,36$ \\
\hline $\begin{array}{l}\text { 3. Bed } \\
\text { (VIP, K1,K2,K3) }\end{array}$ & 20.056 .438 & 22.327 & 898,30 \\
\hline 4. Kipas (K3) & 525.000 & 10.915 & 48,10 \\
\hline 5. Kulkas (VIP) & 2.625 .000 & 1.353 & $1.940,13$ \\
\hline $\begin{array}{l}\text { 6. } \quad \text { Kursi } \\
\text { penunggu (VIP) }\end{array}$ & 875.000 & 1.353 & 646,71 \\
\hline $\begin{array}{l}\text { c. Biaya } \\
\text { pemeliharaan }\end{array}$ & 96.200 .000 & 22.327 & $4.308,68$ \\
\hline 1. Kelas VIP & & 1.353 & \\
\hline 2. $\quad$ Kelas 1 & & 2.661 & \\
\hline 3. Kelas 2 & & 7.398 & \\
\hline 4. $\quad$ Kelas 3 & & 10.915 & \\
\hline
\end{tabular}

4. Membebankan biaya ke produk Dalam tahap ini, biaya aktivitas dibebankan keproduk berdasarkan konsumsi masing-masing aktivitas produk. Pembebanan biaya overhead dari tiap aktivitas ke setiap kamar dihitung dengan rumus menurut Supriyono (2002:234) yaitu:

BOP yang dibebankan $=$ tarif/unit cost drivers $x$ cost driving yang dipilih

\section{Setelah diperoleh hasil} perhitungan total biaya rawat inap, kemudian dibagi dengan jumlah hari lama pasien dirawat selama satu tahun pada masing-masing kelas rawat inap, karena kita akan menghitung tarif rawat inap RSUD Hasanuddin Damrah Bengkulu Selatan pada masing-masing kelas perhari.

\section{Tabel 6}

Tarif Jasa Rawat Inap Kelas VIP

\begin{tabular}{|l|l|r|r|r|}
\hline No & Aktivitas & $\begin{array}{r}\text { Tarif } \\
\text { Cost } \\
\text { Driver } \\
(\mathrm{Rp})\end{array}$ & \multicolumn{1}{|c|}{ Driver } & Total (Rp) \\
\hline 1 & Biaya perawat & $31.710,49$ & 1.353 & $42.904 .292,97$ \\
\hline 2 & Biaya listrik & 706,86 & $37.207,5$ & $26.300 .493,45$ \\
\hline 3 & Biaya air & 718,64 & 1.353 & $972.319,92$ \\
\hline 4 & Biaya laundry & 486,854 & 1.353 & $658.713,462$ \\
\hline 5 & Biaya konsumsi & 4.059 & $5.820,83$ & 23.626 .952 \\
\hline 6 & Biaya kebersihan & $3.239,05$ & 362 & $1.172 .536,1$ \\
\hline
\end{tabular}

\begin{tabular}{|l|l|r|r|r|}
\hline 7 & $\begin{array}{l}\text { Biaya } \\
\text { administrasi }\end{array}$ & $18.237,12$ & 205 & $3.738 .609,6$ \\
\hline 8 & $\begin{array}{l}\text { Biaya depresiasi } \\
\text { gedung }\end{array}$ & $27.290,23$ & 362 & $9.879 .063,26$ \\
\hline 9 & $\begin{array}{l}\text { Biaya } \\
\text { pemeliharaan }\end{array}$ & $4.308,68$ & 1.353 & $5.829 .644,04$ \\
\hline 10 & $\begin{array}{l}\text { Biaya depresiasi } \\
\text { fasilitas }\end{array}$ & $3.548,90$ & 11.412 & $40.500 .046,8$ \\
\hline & AC & 898,304 & 22.327 & $20.056 .433,41$ \\
\hline & Bed & $1.183,36$ & 4.014 & $4.750 .007,04$ \\
\hline & TV & $1.940,13$ & 1.353 & $2.624 .995,89$ \\
\hline & Kulkas & 646,71 & 1.353 & $874.998,63$ \\
\hline & Kursi penunggu & & $183.889 .106,57$ \\
\hline \multicolumn{3}{|c|}{ Total Biaya Untuk Kelas VIP } & 1.353 \\
\hline \multicolumn{3}{|c|}{ Jumlah Hari Pakai } \\
\hline \multicolumn{4}{|c|}{ Rawat Inap Per Kamar } \\
\hline Sumber: Diolah oleh penulis (2018) & & $135.912,13$ \\
\hline
\end{tabular}

Tabel 7

Tarif Jasa Rawat Inap Kelas I

\begin{tabular}{|c|c|c|c|c|}
\hline No & Aktivitas & $\begin{array}{l}\text { Tarif } \\
\text { Cost } \\
\text { Driver } \\
\text { (Rp) }\end{array}$ & Driver & Total (Rp) \\
\hline 1 & Biaya perawat & $31.710,49$ & 2.661 & $84.381 .613,89$ \\
\hline 2 & Biaya listrik & 706,86 & $65.141,28$ & $46.045 .765,18$ \\
\hline 3 & Biaya air & 718,64 & 2.661 & $1.912 .301,04$ \\
\hline 4 & Biaya laundry & 486,85 & 2.661 & $1.295 .507,85$ \\
\hline 5 & Biaya konsumsi & 7.983 & $5.820,83$ & 46.468 .085 \\
\hline 6 & $\begin{array}{l}\text { Biaya } \\
\text { kebersihan }\end{array}$ & $3.239,05$ & 362 & $1.172 .536,1$ \\
\hline 7 & $\begin{array}{l}\text { Biaya } \\
\text { administrasi }\end{array}$ & $18.237,12$ & 515 & $9.392 .116,8$ \\
\hline 8 & $\begin{array}{l}\text { Biaya depresiasi } \\
\text { gedung }\end{array}$ & $27.290,23$ & 362 & $9.879 .063,26$ \\
\hline 9 & $\begin{array}{l}\text { Biaya } \\
\text { pemeliharaan }\end{array}$ & $4.308,68$ & 2.661 & $11.465 .397,48$ \\
\hline 10 & $\begin{array}{l}\text { Biaya depresiasi } \\
\text { fasilitas }\end{array}$ & & & \\
\hline & $\mathrm{AC}$ & $3.548,90$ & 11.412 & $40.500 .046,8$ \\
\hline & Bed & 898,30 & 22.327 & $20.056 .344,1$ \\
\hline & TV & $1.183,36$ & 4.014 & $4.750 .007,04$ \\
\hline \multicolumn{4}{|c|}{ Total Biaya Untuk Kelas VIP } & $277.318 .784,54$ \\
\hline \multicolumn{4}{|c|}{ Jumlah Hari Pakai } & 2.661 \\
\hline \multicolumn{4}{|c|}{ Tarif Rawat Inap Per Kamar } & $104.216,00$ \\
\hline
\end{tabular}

Tabel 8

Tarif Jasa Rawat Inap Kelas II

\begin{tabular}{|l|l|r|r|r|}
\hline No & Aktivitas & $\begin{array}{c}\text { Tarif } \\
\text { Cost } \\
\text { Driver } \\
(\mathrm{Rp})\end{array}$ & Driver & \multicolumn{1}{|c|}{ Total (Rp) } \\
\hline 1. & Biaya perawat & $31.710,49$ & 7.398 & 234.594 .205 \\
\hline 2 & Biaya listrik & 706,86 & $81.103,04$ & $128.014 .494,9$ \\
\hline 3 & Biaya air & 718,64 & 7.398 & $5.316 .498,72$ \\
\hline 4 & Biaya laundry & 486,85 & 7.398 & $3.601 .716,3$ \\
\hline
\end{tabular}




\begin{tabular}{|c|c|c|c|c|}
\hline 5 & Biaya konsumsi & 22.194 & $5.820,83$ & 129.187 .501 \\
\hline 6 & Biaya kebersihan & $3.239,05$ & 550 & $1.781 .477,5$ \\
\hline 7 & $\begin{array}{l}\text { Biaya } \\
\text { administrasi }\end{array}$ & $18.237,12$ & 1.263 & $23.033 .482,56$ \\
\hline 8 & $\begin{array}{l}\text { Biaya depresiasi } \\
\text { gedung }\end{array}$ & $27.290,23$ & 550 & $15.009 .626,5$ \\
\hline 9 & $\begin{array}{l}\text { Biaya } \\
\text { pemeliharaan }\end{array}$ & $4.308,68$ & 7.398 & $31.875 .614,64$ \\
\hline 10 & $\begin{array}{l}\text { Biaya depresiasi } \\
\text { fasilitas }\end{array}$ & & & \\
\hline & $\mathrm{AC}$ & $3.548,90$ & 11.412 & $40.500 .046,8$ \\
\hline & Bed & 898,30 & 22.327 & $20.056 .344,1$ \\
\hline \multicolumn{4}{|c|}{ Total Biaya Untuk Kelas VIP } & $632.971 .008,02$ \\
\hline \multicolumn{4}{|c|}{ Jumlah Hari Pakai } & 7.398 \\
\hline \multicolumn{4}{|c|}{ Tarif Rawat Inap Per Kamar } & $85.559,75$ \\
\hline
\end{tabular}

Tabel 9

Tarif Jasa Rawat Inap Kelas III

\begin{tabular}{|c|c|c|c|c|}
\hline No & Aktivitas & $\begin{array}{c}\text { Tarif } \\
\text { Cost } \\
\text { Driver } \\
\text { (Rp) }\end{array}$ & Driver & Total (Rp) \\
\hline 1 & Biaya perawat & $31.710,49$ & 10.915 & $346.119 .998,4$ \\
\hline 2 & Biaya listrik & 706,86 & $55.011,6$ & $38.885 .499,58$ \\
\hline 3 & Biaya air & 718,64 & 10.915 & $7.843 .955,6$ \\
\hline 4 & Biaya laundry & 486,85 & 10.915 & $5.313 .967,75$ \\
\hline 5 & Biaya konsumsi & 32.745 & $5.820,83$ & 190.603 .078 \\
\hline 6 & Biaya kebersihan & $3.239,05$ & 621 & $2.011 .450,05$ \\
\hline 7 & $\begin{array}{l}\text { Biaya } \\
\text { administrasi }\end{array}$ & $18.237,12$ & 1.975 & 36.018 .312 \\
\hline 8 & $\begin{array}{l}\text { Biaya depresiasi } \\
\text { gedung }\end{array}$ & $27.290,23$ & 621 & $16.947 .232,83$ \\
\hline 9 & $\begin{array}{l}\text { Biaya } \\
\text { pemeliharaan }\end{array}$ & $4.308,68$ & 10.915 & $47.029 .242,2$ \\
\hline 10 & $\begin{array}{l}\text { Biaya depresiasi } \\
\text { fasilitas }\end{array}$ & & & \\
\hline & Kipas angin & 48,10 & 10.915 & $525.011,5$ \\
\hline & Bed & 898,30 & 22.327 & $20.056 .344,1$ \\
\hline \multicolumn{4}{|c|}{ Total Biaya Untuk Kelas VIP } & $711.354 .092,01$ \\
\hline \multicolumn{4}{|c|}{ Jumlah Hari Pakai } & 10.915 \\
\hline \multicolumn{4}{|c|}{ Tarif Rawat Inap Per Kamar } & $65.172,16$ \\
\hline
\end{tabular}

5. Perbandingan Metode Akuntansi Biaya Tradisional dengan Activity Based Costing (ABC) dalam Penetapan Tarif Jasa Rawat Inap.

Membandingkan tarif rawat inap rumah sakit berdasarkan activity based costing ( $\mathrm{ABC}$ )dengan realisasi. Kemudian menganalisis harga rawat inap antara kedua metode tersebut dan membuat kesimpulan.
Tabel 10

Perbandingan Tarif Jasa Rawat Inap Dengan Menggunakan

Metode Activity Based Costing (ABC)

\begin{tabular}{|l|c|c|r|}
\hline $\begin{array}{c}\text { Tipe } \\
\text { Kamar }\end{array}$ & $\begin{array}{c}\text { Metode } \\
\text { Tradisional } \\
\mathbf{( R \mathbf { p } )}\end{array}$ & $\begin{array}{c}\text { Metode } \\
\text { Activity } \\
\text { Based } \\
\text { Cosing } \\
\mathbf{( R p )}\end{array}$ & $\begin{array}{c}\text { Selisih } \\
\text { (Rp) }\end{array}$ \\
\hline Kelas VIP & 250.000 & $135.912,13$ & $114.087,87$ \\
\hline Kelas I & 150.000 & $104.216,00$ & $45.784,00$ \\
\hline Kelas II & 100.000 & $85.559,75$ & $14.440,25$ \\
\hline Kelas III & 75.000 & $65.172,16$ & 9.827 .84 \\
\hline \multicolumn{4}{|c|}{ Sumber: Diolah oleh penulis (2018) }
\end{tabular}

Dari perhitungan diatas, dapat diketahui bahwa hasil perhitungan tarif jasa rawat inap dengan menggunakan metode activity based costing (ABC) untuk kelas VIP Rp 135.912,13 untuk kelas $1 \mathrm{Rp}$ 104.216,00 untuk kelas 2 Rp 85.559,75 dan untuk kelas $3 \mathrm{Rp}$ 65.172,16. Dari hasil tersebut, jika dibandingkan dengan metode tradisional, maka adanya selisih antara metode tradisional dan metode activity based costing ( $\mathrm{ABC})$ yaitu pada kelas VIP Rp 114.087,87, untuk kelas $1 \mathrm{Rp} 45.784,00$, untuk kelas II Rp 14.440,25 dan untuk kelas III sebesar Rp 9.827,84.

Faktor yang menyebabkan adanya selisih antara metode tradisional dan metode activity based costing $(\mathrm{ABC})$ karena pembebanan biaya operasional dalam pelayanan rumah sakit menurut kelas. Fasilitas yang diberikan rumah sakit pada tiap kelas juga akan mempengaruhi besarnya cost driver untuk peritungan metode activity based costing (ABC). Pada aktivitas biaya tradisional biaya operasional yang dibebankan pada kelas dalam rawat inap hanya pada satu cost driver saja. Selanjutnya pada metode activity based costing (ABC) telah mampu mengalokasikan biaya aktivitas ke setiap kamar secara tepat berdasarkan ketentuan masingmasing aktivitas. 
K. KESIMPULAN DAN SARAN

1) Kesimpulan

Berdasarkan data yang diperoleh dan hasil analisis penelitian yang telah dilakukan terhadap tarif jasa rawat inap pada Rumah Sakit Umum Daerah (RSUD) Hasanuddin Damrah Bengkulu Selatan, maka dapat ditarik kesimpulan sebagai berikut :

1. Rumah Sakit Umum Daerah (RSUD) Hasanuddin Damrah Bengkulu Selatan dalam menentukan tarif jasa rawat inap menggunakan metode tradisional. Faktor-faktor yang menjadi pertimbangan rumah sakit dalam menggunakan metode tradisionaladalah keadaan sosial masyarakat dan Surat Keputusan Bupati Bengkulu Selatan Nomor 10 Tahun 2016 tentang Pola Tarif Layanan Kesehatan Rumah Sakit Umum Daerah (RSUD) Hasanuddin Damrah Bengkulu Selatan. Tarif jasa rawat inap yang telah digunakan selama tahun 2018 adalah untuk kelas VIP sebesar Rp 250.000, kelas I sebesar Rp 150.000, kelas II sebesar Rp 100.000, dan untuk kelas III sebesar Rp 75.000.

2. Perhitungan tarif jasa rawat inap menggunakan metode activity based costing ( $\mathrm{ABC}$ )memberikan hasil yang sesuai dengan aktivitasaktivitas yang dibebankan. Untuk tarif jasa rawat inap yang dihitung dengan menggunakan metode activity based costing (ABC) untuk kelas VIP sebesar Rp 135.912,13 kelas I sebesar Rp 104.216,00 kelas II sebesar Rp 85.559,75, dan kelas III sebesar Rp 65.172,16.

3. Dari hasil perhitungan tarif jasa rawat inap dengan menggunakan metode activity based costing (ABC)apabila dibandingkan dengan tarif rawat inap yang berlaku di Rumah Sakit Umum Daerah (RSUD) Hasanuddin
Damrah Bengkulu Selatan saat ini, maka metode activity based costing (ABC) memberikan hasil yang lebih kecil pada seluruh jenis kelas rawat inap. Perbedaan yang terjadi disebabkan karena pembebanan biaya overhead pada masing-masing produk. Pada metode akuntansi biaya tradisionalbiaya overhead pada masing-masing produk hanya dibebankan pada satu cost driver. Akibatnya cenderung terjadi distorsi pada pembebanan biaya overhead. Sedangkan pada metode activity based costing (ABC), biaya overhead pada masing-masing produk dibebankan pada banyaknya cost driver. Sehingga dalam metode activity based costing (ABC), telah mampu mengalokasikan biaya aktivitas ke setiap kamar secara tepat berdasarkan konsumsi masingmasing aktivitas.

\section{2) Saran}

Berdasarkan penelitian yang telah dilakukan penulis memberikan saran kepada Rumah Sakit Umum Daerah (RSUD) Hasanuddin Damrah Bengkulu Selatan sebaiknya mempertimbangkan perhitungan tarif rawat inap dengan menggunakan metode activity based costing (ABC), karena akan memberikan informasi biaya yang lebih akurat.

\section{DAFTAR PUSTAKA}

Ahmad, Firdaus Dunia dan Abdullah, Wasilah. 2012. Akuntansi Biaya. Jakarta: Salemba Empat.

Ahmad, Kamaruddin. 2014. Akuntansi Manajemen. Jakarta: PT Raja Grafindo Persada. 
Carter, William $\mathrm{K}$ dan Usry. 2006. Akuntansi Biaya. Buku 1, Edisi 13. Jakarta: Salemba Empat

Dewi, Sofia Prima dan Kristato, Septian Bayu. 2013. Akuntansi Biaya. Jakarta: In Media.

Hansen, Don R. dan Maryanne M. Mowen. 2004. Akuntansi Manajemen. Jakarta: Salemba Empat.

Hongren dan Foster. 2003, Akuntansi Biaya. Jakarta: Penerbit Erlangga.

Kurniawan, Albert. 2014. Metode Riset untuk Ekonomi dan Bisnis. Bandung: Alfabeta

Mulyadi. 2007. Activity Based Cost System. Yogyakarta: UPP STIM YKPN Yogyakarta.

Rudianto. $2005 . \quad$ Akuntansi Manajemen. Jakarta: Grasindo.

Siregar, Baldric, Suripto, Bambang, Hapsoro, Dody, Widodo, Lo Eko dan Biyanto, Frasto, 2013. Akuntansi Manajemen. Jakarta: Salemba Empat.

Sugiyono. 2015. Metode Penelitian Manajemen. Bandung: Alfabeta

Supriyono. 2002. Akuntansi Biaya dan Akuntansi Manajemen untuk Teknologi Maju dan Globalisasi, Edisi 2. Yogyakarta: BPFE.

Tunggal, Amin Wijaya. 2012. Intisari Activity Based Costing System $(A B C)$ dan Management (ABM). Jakarta: Harvarindo. 